\title{
Corrosion Resistance Studies of Austenitic Stainless Steel Grades in Molten Zinc-Aluminum Alloy Galvanizing Bath
}

\author{
Roland Tolulope Loto • Emre Özcan
}

Submitted: 23 March 2016/Published online: 26 April 2016

(C) ASM International 2016

\begin{abstract}
The corrosion inhibition performance and mechanical behavior of galvanized and heat-treated four newly developed austenitic stainless steel grades and type 316 austenitic stainless steel for application as sink rolls in galvanizing baths of $0.14-0.21 \mathrm{wt} . \%$ aluminum was investigated and compared through immersion corrosion test to determine the weight loss between 168 and $504 \mathrm{~h}$, tensile test, and Charpy impact test. The delta ferrite content of the test samples was observed and estimated through optical microscopy, feritscope, and ONRL diagram. Scanning electron microscopy and energy dispersive spectroscopy were used to characterize the surface microstructure, morphology, and chemical composition of the galvanized coating of the steel samples. Result showed that only two of the newly developed stainless steel compositions were selected for use in fabrication of galvanizing hardware based on the comparisons of corrosion and mechanical performances of tested alloys.
\end{abstract}

Keywords Austenitic stainless steel · Corrosion · Microstructure $\cdot$ Mechanical test

\footnotetext{
R. T. Loto $(\square)$

Department of Mechanical Engineering, Covenant University, Ota, Ogun, Nigeria

e-mail: tolu.loto@gmail.com

R. T. Loto

Department of Chemical, Metallurgical \& Materials

Engineering, Tshwane University of Technology, Pretoria, South Africa

E. Özcan

Metallurgical and Materials Engineering Department, Middle East Technical University, Ankara, Turkey
}

\section{Introduction}

Corrosion prevention and control through application of a protective zinc coating to stainless steels is one of the most reliable, cost-effective, long-lasting, and environmentally friendly methods in current application [1, 2]. Automotive body parts and components, office cabinets and drawers, doors, gates and body parts of air conditioners, refrigerators, dishwashers, roof tops, etc., are some of the major areas of application for galvanized steel sheets; however, increase in demand of galvanized sheet has resulted in problems in quality and efficiency of production. High-grade galvanized steel in sufficient quantity is required to match the increasing industrial demand internationally. Stainless steels fabrications for zinc bath hardware of continuous galvanizing lines corrode significantly due to various factors in molten zinc and aluminum media. At present, there are over 450 continuous galvanizing lines where the coating of steel sheet with liquid zinc-aluminum alloy is performed worldwide (Fig. 1) [3]. Studies on the development of more resistant and cost-efficient materials have been scarce until the last decade. The challenge to develop superior materials in continuous galvanizing lines is ever increasing [4]. The corrosion resistance of sink rolls is vital industrially due to the effect of corrosion damage on the surface properties of the coating of steel strip which is unacceptable for a continuous galvanizing line. Halting the galvanizing process due to corrosion damage from liquid zinc and its alloys to the bath hardware results in additional cost and time wastage; thus, material selection for sink rolls must be carefully done. Industrial application of sink rolls involves passage of the steel strip to be coated through the galvanizing bath on continuous 
galvanizing lines. It operates in a very harsh solution which is very corrosive at high temperatures. Steps to prevent damage on the steel strip to be coated involve adequate maintenance of the sink roll which brings high costs to the galvanizing process. Corrosion performance of the steel grade for application as sink roll is highly important. Improvement in the corrosion performance of sink rolls would significantly increase the productivity of the continuous galvanizing lines. Previous study on the corrosion behavior of austenitic stainless steels in galvanizing baths with 0.135 wt.\% aluminum content showed that steel alloys have better corrosion resistance than ferritic and martensitic steels [5, 6]. Xu et al. [7] investigated the corrosion behavior of AISI 410, AISI 316L, and AISI 1015 steels at 465, 500, and $520^{\circ} \mathrm{C}$, respectively, for 96 to $408 \mathrm{~h}$ in galvanizing media. Observation showed that increase in temperature accelerated the corrosion rates of the test alloys, while 316L stainless steel had the lowest corrosion rate.
Zhang et al. [8] studied type $316 \mathrm{~L}$ stainless steel in industrial $\mathrm{Zn}-\mathrm{Al}$ galvanizing bath, with an effective $\mathrm{Al}$ content of $0.2 \mathrm{wt} . \%$. Results showed that samples welded to the supporting roll arms and sides of the sink roll experienced significant accumulation. SEMEDS analyses showed that the buildup consists of an inner layer; the product of the steel reaction with the bath metal. The intermetallic phase formed at the reaction front of the samples provided a thermodynamically favorable base for the attachment and further buildup of suspended dross particles on the sample surfaces. Another study showed corrosion resistance of $316 \mathrm{~L}$ steel was proven to be higher than $\mathrm{Fe}_{3} \mathrm{AI}$ in galvanizing, galfan, and galvalume baths; however, in aluminizing baths they were similar. $\mathrm{FeCrSi}$ shows better than $316 \mathrm{~L}$ and Fe3AI corrosion resistance in pure $\mathrm{Zn}, \mathrm{Zn}-55 \mathrm{AI}$, and AI-8Si baths from static test analysis. Chemical composition and bath temperature played significant roles in corrosion resistance and intermetallic layer formation [9]. Saurabh and Kshirsagar [10] solicited

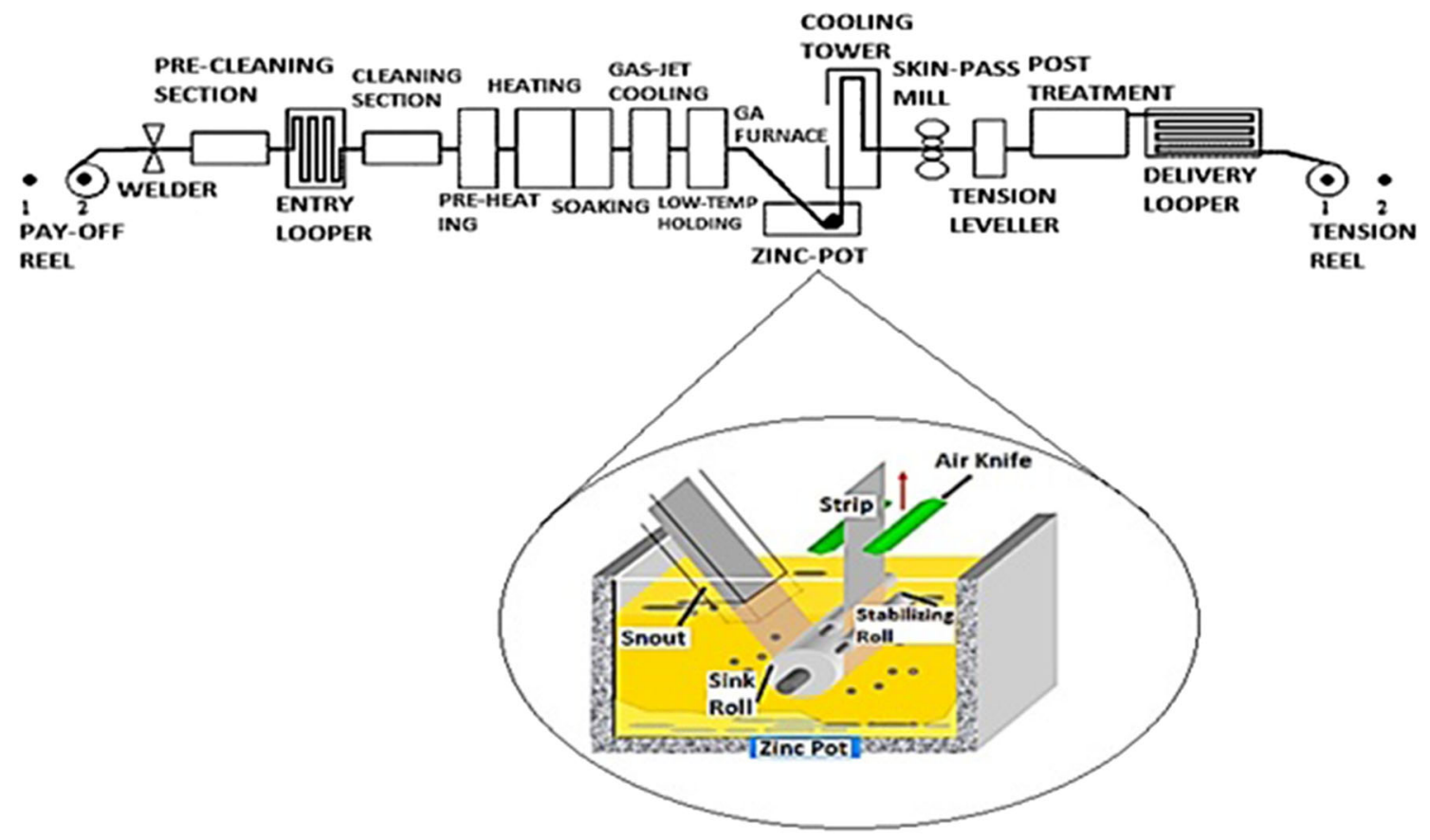

Fig. 1 Schematic of a continuous galvanizing line

Table 1 Chemical compositions of five candidate steels tested in this study

\begin{tabular}{lcccccccc}
\hline Steel no. & $\mathrm{C}$ & $\mathrm{Si}$ & $\mathrm{Mn}$ & $\mathrm{P}$ & $\mathrm{S}$ & $\mathrm{Cr}$ & $\mathrm{Ni}$ & $\mathrm{Mo} \mathrm{Others}$ \\
\hline 1 & 0.018 & 0.330 & 10.18 & 0.020 & 0.004 & 23.70 & 8.50 & $\mathrm{~N}, \mathrm{Cu}, \mathrm{V}, \mathrm{W}$ \\
2 & 0.003 & 0.409 & 1.04 & 0.005 & 0.006 & 24.04 & 11.16 & $\mathrm{~N}, \mathrm{Cu}, \mathrm{V}, \mathrm{W}$ \\
3 & 0.004 & 0.443 & 8.07 & 0.006 & 0.005 & 18.95 & 9.24 & $\mathrm{~N}, \mathrm{Cu}, \mathrm{V}, \mathrm{W}$ \\
4 (ALSI 316L) & 0.016 & 1.050 & 0.97 & 0.015 & 0.013 & 19.97 & 9.32 & $\mathrm{~N}: 0.123$ \\
5 & 0.024 & 0.320 & 1.73 & 0.010 & 0.005 & 24.07 & 13.36 & $\mathrm{~N}, \mathrm{Cu}, \mathrm{V}, \mathrm{W}$ \\
\hline
\end{tabular}


an alternative material (AT101) prepared by centrifugal casting methods and thermal-spray coating on stainless steel 316L sink roll surface to extend the service life of the sink roll. The roll made by AT101 results in better performance than the traditional roll made by stainless steel 316L. The pickup of dross on the sink roll surface is minimized by the formation of inhibition layer on the surface of roll which minimizes the deposition on roll. Thermal-spray coating of the material on traditionally used sink roll made of stainless steel 316L improved the hardness and corrosion resistance at elevated temperatures as well as reducing the formation of dross buildup. This study aims to develop unique stainless steel compositions and specifications for application as sink roll material in continuous galvanizing lines with the objective of extending the working lifespan of sink rolls in comparison to the conventionally applied materials and assess comparatively their electrochemical and mechanical characteristics with AISI $316 \mathrm{~L}$ in specific galvanizing medium of 0.14 to 0.21 wt.\% aluminum through immersion test analysis, tensile and Charpy impact tests, and scanning electron microscopy characterization.

\section{Experimental Procedure}

\section{Material Preparation}

The test samples used for this investigation consist of four newly developed steel alloys with carbon equal to or less than 0.03 wt.\% and austenitic stainless steel type $316 \mathrm{~L}$ (AISI 316L) centrifugally cast in Sweden. The samples were obtained in tubular forms with external diameter of

Table 2 Corrosion test conditions

\begin{tabular}{lcc}
\hline Steel sample set & Heat treatment condition & Exposure time, h \\
\hline A & Aged at $750{ }^{\circ} \mathrm{C}$ & 504 \\
B & Solution annealed & 168 \\
C & Solution annealed & 504 \\
D & Solution annealed & 504 \\
\hline
\end{tabular}

$400 \mathrm{~mm}$, internal diameter of $311 \mathrm{~mm}$, and the length of $370 \mathrm{~mm}$. They were solution annealed at $1100{ }^{\circ} \mathrm{C}$ for $3 \mathrm{~h}$ after casting to remove carbides and nitrides within their microstructure before having been quenched in water. Their chemical compositions are represented in Table 1. Twenty steel samples for the corrosion test were machined from steel tubes to about $40 \mathrm{~mm}$ in diameter and $4 \mathrm{~mm}$ in length with a surface area of $3025 \mathrm{~mm}^{2}$. Each of them was drilled at the center for suspension. Two sets of 40 steel samples and three sets of 60 steel samples were wet machined from 5 steel sample rings to about $5 \mathrm{~mm}$ tolerance of their final dimensions and were heat treated before tensile and impact tests.

\section{Immersion Corrosion Tests}

Weighted steel samples were fully and separately immersed in molten zinc-aluminum alloy galvanizing bath, an electric resistance-heated furnace operating at $380 \mathrm{~kW}$ with a $10 \mathrm{~L} \mathrm{SiC/Graphite} \mathrm{crucible.} \mathrm{Four} \mathrm{sets} \mathrm{of} \mathrm{steel} \mathrm{sam-}$ ples were suspended in the bath consisting of 5 specimens and one set of them was taken out after $168 \mathrm{~h}$, while the other 3 sets were taken out after $504 \mathrm{~h}$ according to ASTM G 01-03 [11] as shown in Table 2, after which their coatings are acid pickled and their weight losses were measured according to ASTM G31-72 [12]. The corrosion test samples taken out from galvanizing bath were preserved in non-oxidizing environments till their coatings have been removed.

The corrosion rates of the investigated steel were determined according to $\mathrm{Eq} 1$.

The corrosion rate $(R)$ calculation is from this Eq 1:

$R=\left[\frac{87.6 W}{D A T}\right]$,

where $W$ is the weight loss in milligrams, $D$ is the density in $\mathrm{g} / \mathrm{cm}^{2}, A$ is the area in $\mathrm{cm}^{2}$, and $T$ is the time of exposure in $\mathrm{h}$.

Before the steel samples are placed in the galvanizing solution in preparation for the immersion corrosion test, the furnace is charged with pure zinc ingots. After which, the

Fig. 2 Image of corrosion steel samples in the molten zincaluminum alloy suspended with titanium wires

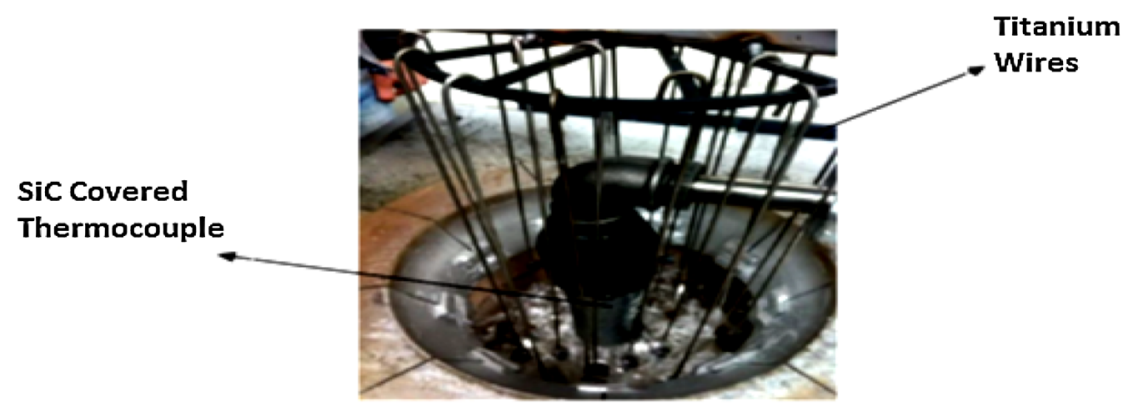


furnace is heated to about $200{ }^{\circ} \mathrm{C}$ for $3 \mathrm{~h}$ for the volatile elements in the ceramic crucible and on the zinc ingots to be evaporated. The temperature is then increased to $550{ }^{\circ} \mathrm{C}$, with the purpose of melting the zinc. Thereafter, slag is taken from its surface and it is alloyed with pure aluminum wires to attain the simulated condition of the galvanizing media. The corrosion steel samples are immersed into the medium with the aid of pure titanium wires as shown in Fig. 2. The wires are changed every $72 \mathrm{~h}$ due to deterioration from the effects of corrosion. The chemical composition of the galvanizing bath is maintained through charging of the aluminum and/or zinc periodically.

\section{Heat Treatment}

Samples for tensile and impact test were heat treated in Protherm PLF 120/10 annealing furnace which has a working temperature of $1210{ }^{\circ} \mathrm{C}$ and internal volume of $10 \mathrm{~L}$ as shown in Table 3 below.

Tensile and Charpy Impact Tests

Instron 5582 tensile testing device with $100 \mathrm{kN}$ of load capacity was used for tensile testing in this investigation. Tensile testing was conducted in accordance with the standard EN 10002-1: tensile testing of metallic materials [13]. Pendulum-type Tinius Olsen impact testing machine was used for the impact tests in accordance with the standard ISO 148-1:2009 metallic materials-Charpy pendulum impact test—part 1: test method [14].

\section{Delta Ferrite Composition Analysis}

The delta ferrite composition of the steels samples were determined before further tests through metallographic method, with the aid of an AWS Calibrated Feritscope ${ }^{\circledR}$ FMP 30 and Schaeffler's, Delong's WRC-1992. Samples extracted from the steel tubes were grounded on automated wet sanding device and polished with 6,3 , and $0.3 \mu$ polishers, respectively. Etching was done with $100 \mathrm{ml}$ $\mathrm{HCl}+25 \mathrm{~g}$. picric acid solutions in order to explicitly reveal the austenite/ferrite boundaries after which they were imaged via Olympus PMEU-F200 optical

Table 3 Heat treatment conditions and time intervals

\begin{tabular}{ll}
\hline Heat treatment & \multicolumn{1}{c}{ Time period } \\
\hline Solution annealed & $3 \mathrm{~h}$ then water quenched \\
Galvanizing temp. $\left(460{ }^{\circ} \mathrm{C}\right)$ & $504 \mathrm{~h}$ \\
Age treated $\left(750{ }^{\circ} \mathrm{C}\right)$ & $16 \mathrm{~h}$ then water quenched \\
Age treated + galvanizing & $16 \mathrm{~h}$ water quenched then $505 \mathrm{~h}$ at \\
temp. & $460{ }^{\circ} \mathrm{C}$ \\
\hline
\end{tabular}

microscope with QCapture Pro V. 5.1.1.14 Software. Subsequently, estimations of the delta ferrite contents were also done using Schaeffler's, Delong's, WRC-1992 and the modified version from Oak Ridge National Laboratory to confirm the delta ferrite contents.

\section{Scanning Electron Microscopy Characterization}

Scanning electron microscopy was used to characterize the microstructure and chemical composition of the galvanized coating of the steel samples using Jeol JSM-6400F UHR Analytical FEG SEM, a state of- the-art Ultra-High Resolution Analytical Thermal Field Emission Gun Scanning Electron Microscope which successfully combines ultrahigh resolution imaging with optimized analytical functionality. SEM micrographs images were taken and recorded.

\section{Result and Discussion}

\section{Immersion Corrosion Test}

Table 4 shows the initial weights, final weights, and weight losses of the steel samples exposed for $504 \mathrm{~h}$ molten zincaluminum alloy. In Table 4, four set of samples are visible each with specific heat treatment condition and exposure time. Each set consists of 5 specimens and every one of them represents one candidate steel. In Table 5, set B has an exposure time of $168 \mathrm{~h}$ while set $\mathrm{C}$ has $504 \mathrm{~h}$. This results in samples in set $\mathrm{C}$ corroding faster than those in set B. Samples in set $\mathrm{C}$ were exposed to the galvanizing solution 3 times longer than those in set $\mathrm{B}$, yet the difference in weight loss is about 5\%. The reason for these results is that corrosion products slowly cover up surfaces of specimens, thus slow down the acceleration of corrosion. In practice, corrosion products go away as the sink roll rotates to pass the steel strip to be coated.

The results in Table 6 show that aging treatment $(16 \mathrm{~h}$ at $750{ }^{\circ} \mathrm{C}$ ) does not significantly impact the corrosion rates of steel samples. The difference between the aged and nonaged specimens is minimal. The corrosion rates and weight loss for steels 1, 2, 3, and AISI 316L are slightly greater in the aged samples when compared to non-aged samples. In comparison to the other steel samples, aged samples of steel 5 corroded faster at lower levels when compared with non-aged samples. In addition to weight loss results, weight loss per unit area results is also depicted. The results for set B (immersed $168 \mathrm{~h}$ ) are significantly lesser than the other sets (immersed $504 \mathrm{~h}$ ); however, the corrosion rates of set $\mathrm{B}$ are significantly higher than the other sets due to the fact that corrosion occurs instantaneously after being immersed 
Table 4 Weight loss data for the steel samples

\begin{tabular}{lccc}
\hline Steel sample & Initial weight, g & Final weight, g & Weight loss, g \\
\hline 1A & 38.578 & 30.234 & 8.343 \\
2A & 39.806 & 33.984 & 5.822 \\
3A & 38.342 & 33.174 & 5.168 \\
4A & 39.416 & 17.422 & 21.994 \\
5A & 39.375 & 33.398 & 5.978 \\
1B & 39.478 & 34.991 & 4.487 \\
2B & 38.372 & 34.163 & 4.208 \\
3B & 38.955 & 35.018 & 3.937 \\
4B & 38.712 & 33.806 & 4.906 \\
5B & 39.845 & 35.194 & 4.650 \\
1C & 39.778 & 33.558 & 6.220 \\
2C & 39.272 & 34.759 & 4.514 \\
3C & 40.375 & 34.051 & 6.324 \\
4C & 37.991 & 32.504 & 5.487 \\
5C & 39.320 & 33.253 & 6.068 \\
1D & 39.182 & 32.753 & 6.429 \\
2D & 39.588 & 34.413 & 5.175 \\
3D & 38.778 & 33.255 & 5.523 \\
4D & 39.181 & 33.604 & 5.576 \\
5D & 40.064 & 33.019 & 7.045 \\
\hline
\end{tabular}

Table 5 Comparison of weight loss results at specific time intervals

\begin{tabular}{lcccc}
\hline $\begin{array}{l}\text { Steel } \\
\text { sample }\end{array}$ & $\begin{array}{c}\text { Initial } \\
\text { weight, g }\end{array}$ & $\begin{array}{c}\text { Final } \\
\text { weight, g }\end{array}$ & $\begin{array}{c}\text { Weight } \\
\text { loss, g }\end{array}$ & $\begin{array}{c}\text { Weight loss } \\
\text { differential, \% }\end{array}$ \\
\hline 1B & 39.478 & 34.991 & 4.487 & 11.36 \\
2B & 38.372 & 34.163 & 4.208 & 10.96 \\
3B & 38.955 & 35.018 & 3.937 & 10.10 \\
4B & 38.712 & 33.806 & 4.906 & 12.67 \\
5B & 39.845 & 35.194 & 4.650 & 11.67 \\
1C & 39.778 & 33.558 & 6.220 & 15.63 \\
2C & 39.272 & 34.759 & 4.514 & 11.49 \\
3C & 40.375 & 34.051 & 6.324 & 15.66 \\
4C & 37.991 & 32.504 & 5.487 & 14.44 \\
5C & 39.320 & 33.253 & 6.068 & 15.43 \\
\hline
\end{tabular}

into the bath, then slows with the accumulation of dross onto samples $[15,16]$.

Observation of the results for steel samples shows that samples 2 and AISI 316L have a higher corrosion resistance than other samples in solution annealed condition after $504 \mathrm{~h}$. For shorter exposure time, AISI 316L has the lowest corrosion resistance. The delta ferrite content of AISI $316 \mathrm{~L}$ results in sigma and chi $(\chi)$ phase formation. The formation is responsible for the severe deterioration of the aged sample as shown in the corrosion rates of sample 4A as delta ferrite phase selectively deteriorates before austenite in the galvanizing solution [17-19]. The
Table 6 Corrosion rates and mass loss per unit area values for corrosion specimen

\begin{tabular}{lccc}
\hline $\begin{array}{l}\text { Steel } \\
\text { sample }\end{array}$ & $\begin{array}{c}\text { Area of } \\
\text { exposure, } \mathrm{mm}^{2}\end{array}$ & $\begin{array}{c}\text { Weight loss/area, } \\
\mathrm{g} / \mathrm{mm}^{2}\end{array}$ & $\begin{array}{c}\text { Corrosion } \\
\text { rate } \times 10^{4}, \mathrm{~g} / \mathrm{cm}^{2} \mathrm{~h}\end{array}$ \\
\hline 1A & 3017.664 & 2.7649 & 5.4858 \\
2A & 3027.472 & 1.9230 & 3.8155 \\
3A & 3007.356 & 1.7183 & 3.4094 \\
4A & 3025.960 & 7.2685 & 14.4217 \\
5A & 3025.463 & 1.9758 & 3.9202 \\
1B & 3026.469 & 1.4825 & 8.8243 \\
2B & 3011.374 & 1.3975 & 8.3185 \\
3B & 3009.871 & 1.3082 & 7.7867 \\
4B & 3018.420 & 1.6253 & 9.6743 \\
5B & 3032.501 & 1.5335 & 9.1279 \\
1C & 3025.960 & 2.0554 & 4.0783 \\
2C & 3018.420 & 1.4953 & 2.9669 \\
3C & 3033.759 & 2.0844 & 4.1357 \\
4C & 3016.653 & 1.8189 & 3.6089 \\
5C & 3021.186 & 2.0083 & 3.9848 \\
1D & 3030.497 & 2.1215 & 4.2093 \\
2D & 3030.497 & 1.7077 & 3.3883 \\
3D & 3023.195 & 1.8267 & 3.6245 \\
4D & 3020.425 & 1.8462 & 3.6630 \\
5D & 3030.243 & 2.3250 & 4.6132 \\
\hline & & &
\end{tabular}

corrosion performance of sample 2, 3, and 5 showed generally stable corrosion resistance at the applied heat treatment conditions. The order of corrosion performance is sample $2>$ sample $3>$ sample 5 . Visual observation of the corroded samples shows that the surface roughness of samples $1,2,3$, and 4 are generally the same, while the surface of sample 5 has smoother and much cleaner. This is an optimal advantage in industrial applications. Rough sink roll surfaces mark steel strip to be coated leading to unplanned line stoppages. Figure 3 shows the actual image of steel sample 4A (AISI 316L) and 5A, aged at $750{ }^{\circ} \mathrm{C}$ after immersion into the galvanizing bath. Observation shows that AISI 316L steel sample deteriorated due to pitting corrosion in comparison to steel sample 5. The entire surface deteriorated due to molten metal corrosion resulting in pitting corrosion within the galvanizing media. In industrial application, the deterioration can limit the performance.

\section{Scanning Electron Microscopy Characterization of Galvanizing Bath}

Table 7 shows the spectral analytical results of the galvanizing bath composition at limits of galvanizing. Figure 4 shows the micrograph of the coating morphology. Ternary phase $\eta$ formation with a non-uniform dimension is 
Fig. 3 Corroded steel samples 4A (black sample) and 5A

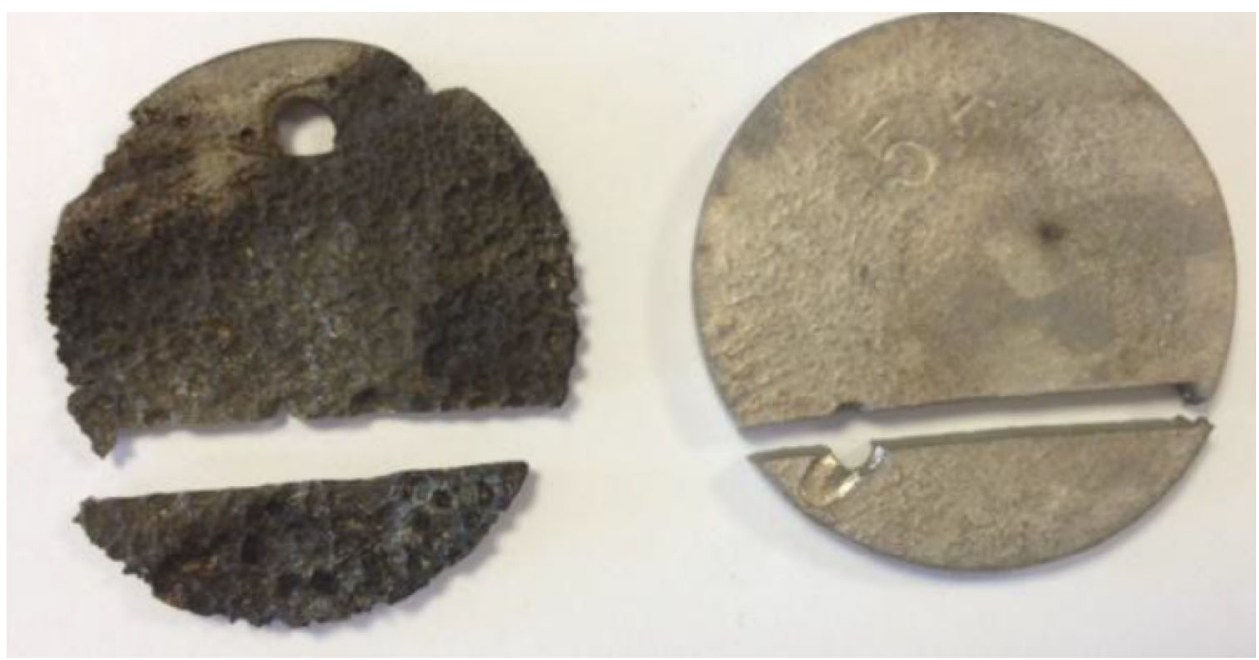

Table 7 Typical chemical composition of galvanizing bath

\begin{tabular}{ccccccccccccccc}
\hline $\mathrm{Al}$ & $\mathrm{Cu}$ & $\mathrm{Fe}$ & $\mathrm{Pb}$ & $\mathrm{Ag}$ & $\mathrm{Cd}$ & $\mathrm{Mg}$ & $\mathrm{Mn}$ & $\mathrm{Ni}$ & $\mathrm{Sb}$ & $\mathrm{Sn}$ & $\mathrm{Ti}$ & $\mathrm{Cr}$ & $\mathrm{Zn}$ \\
\hline 0.184 & 0.017 & 0.018 & 0.028 & 0.002 & 0.009 & $<0.001$ & 0.003 & 0.021 & 0.0878 & 0.916 & $<0.005$ & 0.495 & Remainder \\
\hline
\end{tabular}

Fig. 4 SEM image of galvanize coating

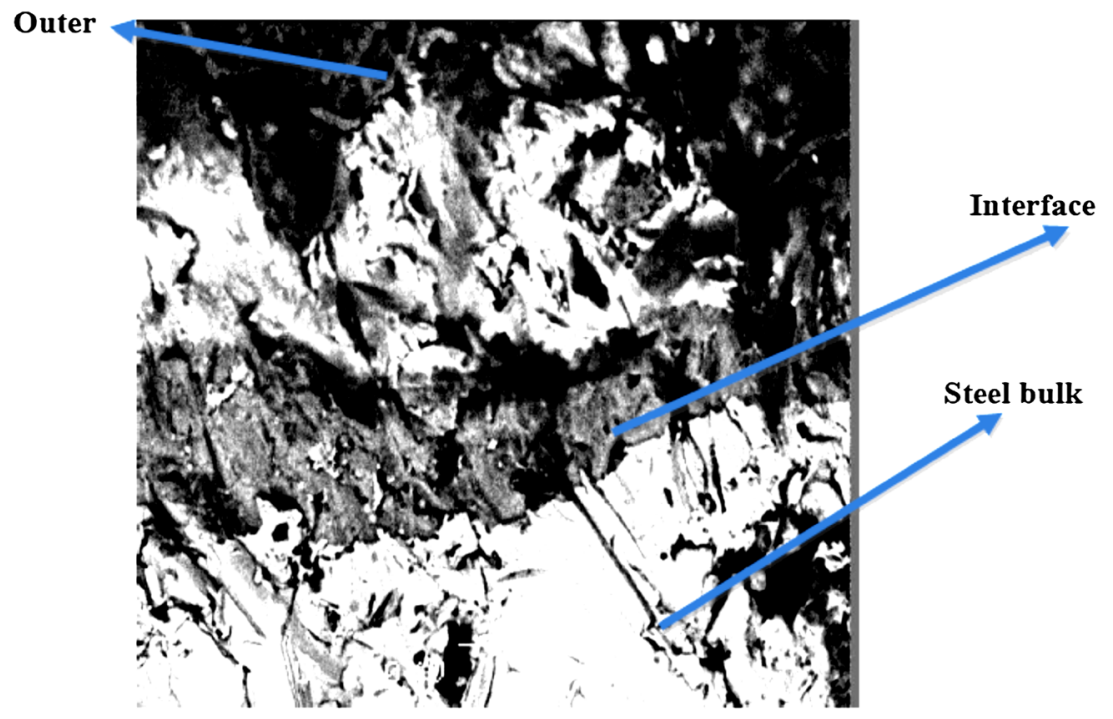

observed in the galvanizing media containing aluminum content higher than 0.14 wt.\%. Results from EDS analysis show that the ternary alloy consist of $\mathrm{Fe}, \mathrm{Zn}$, and $\mathrm{Al}$ with a stoichiometry of $\mathrm{Fe}_{2} \mathrm{Al}_{5-x} \mathrm{Zn}_{x}[20,21]$. Figure 5 shows the EDS analysis results from the coating interface where ternary $\mathrm{Fe}_{2} \mathrm{Al}_{5-x} \mathrm{Zn}_{x}$ phase is formed. However, Table 8 shows the weight and atomic percentages of $\mathrm{Fe}_{2} \mathrm{Al}_{5-x} \mathrm{Zn}_{x}$ phase. The chemical composition of ternary alloy layer is similar to the stoichiometry of $\mathrm{Fe}_{2} \mathrm{Al}_{5-x} \mathrm{Zn}_{x}$ phase based on atomic and weight percentages as depicted in Table 8 . The results are also closely similar to the ones found from literature [20-23]. Zhang et al. [8] found $\mathrm{Fe}_{2} \mathrm{Al}_{5-x} \mathrm{Zn}_{x}$ phase containing approximately 50.2 atomic $\% \mathrm{Al}, 28.8 \% \mathrm{Fe}$, 19.3 Zn, $1.1 \% \mathrm{Mo}$, and $0.6 \% \mathrm{Cr}$. The slight differentiation between the diffusion kinetics of two galvanizing baths inhibits the perfect exact matching of chemical compositions of eta phases of the two studies [8].

The chemical compositions of the outer surface of the galvanized samples were also found to be in close comparison to the ones in the literature like the stainless steelcoating interface morphology as shown in Fig. 6 and Table 9. Minimal diffusion of Fe to the zinc coating was observed on the EDS result of the outer layer as is common on typical galvanized coating [16]. $\mathrm{FeZn}_{13}$ and pure zinc 
Fig. 5 EDS analysis pattern for stainless steel-coating interface where $\mathrm{Fe}_{2} \mathrm{Al}_{5-x} \mathrm{Zn}_{x}$ formation is observed

Table 8 Chemical composition of eta $(\eta)$ phase in atomic and weight percent

\begin{tabular}{lcc}
\hline Element & Weight conc $\%$ & Atom conc $\%$ \\
\hline $\mathrm{Al}$ & 24.45 & 41.00 \\
$\mathrm{Si}$ & 2.04 & 3.29 \\
$\mathrm{Cr}$ & 3.54 & 3.08 \\
$\mathrm{Fe}$ & 41.04 & 33.24 \\
$\mathrm{Zn}$ & 26.14 & 18.08 \\
\hline
\end{tabular}

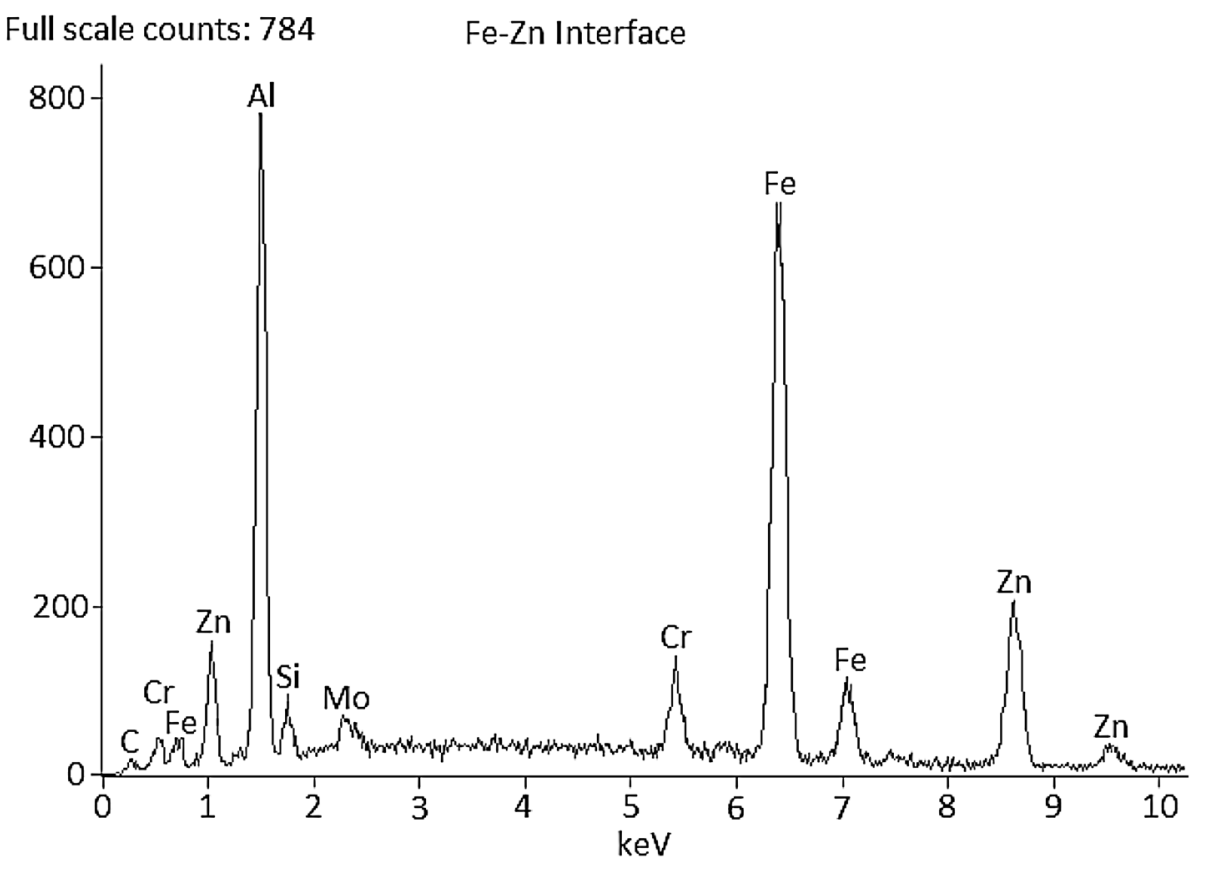

Fig. 6 EDS analysis pattern for outer layer of stainless steelcoating phases are present in this region where the weight percentage of iron is approximately $2 \%$. These phases appeared darker than $\mathrm{Fe}-\mathrm{Al}-\mathrm{Zn}$ phase as can be seen from Fig. 1.

\section{Delta Ferrite Determination}

Delta ferrite is a phase maintained in most of the cast austenitic stainless steels when it cools. It is composed of a BCC crystal lattice and is discontinuously represented in the microstructure. Most cast austenitic alloys generally

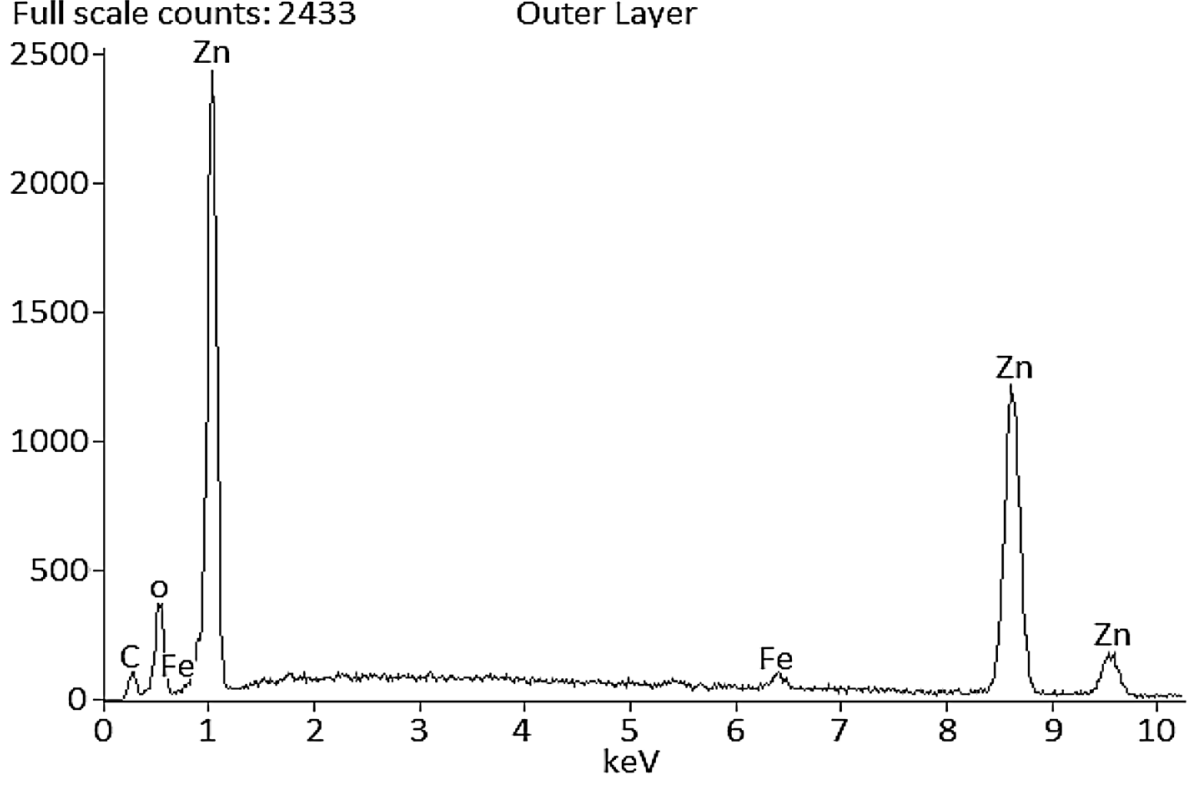


Table 9 Chemical compositions of outer layer of coating in atomic and weight percent

\begin{tabular}{lcc}
\hline Element & Weight conc \% & Atom conc \% \\
\hline $\mathrm{Fe}$ & 1.8 & 2.1 \\
$\mathrm{Zn}$ & 98.2 & 97.9 \\
\hline
\end{tabular}

Table 10 Delta ferrite measurement results with feritscope ${ }^{\circledR}$

\begin{tabular}{lc}
\hline Steel & Delta ferrite $(\%)$ \\
\hline 1 & 2.93 \\
2 & 3.06 \\
3 & 2.49 \\
4 (AISI 316L) & 5.61 \\
5 & 2.5 \\
\hline
\end{tabular}

have delta ferrite composition within the range of 5-20 wt.\% [24]. Determination of the delta ferrite contents of the 5 steel samples was done with the aid of ORNL diagram, optical microscopy image analysis after metallographic preparation ASTM standard E562, and feritscope measurements [25]. Table 10 shows the delta ferrite contents of steel sample from feritscope measurement, while Fig. 7 shows the result from optical microscopy image analysis. Observation of the tables on delta ferrite composition of the samples shows that they have different delta ferrite contents with respect to their chemical compositions. Some of the samples have more austenite promoting elements such as $\mathrm{Ni}, \mathrm{Mn}$, and $\mathrm{N}$, while others have more ferrite promoting elements such as $\mathrm{Cr}, \mathrm{Mo}, \mathrm{V}$, and $\mathrm{Cu}$. Delta ferrite contents have a profound impact on the corrosion resistance behavior and mechanical properties of these steel samples,
Fig. 7 Metallographic image analysis result of AND-5 Steel
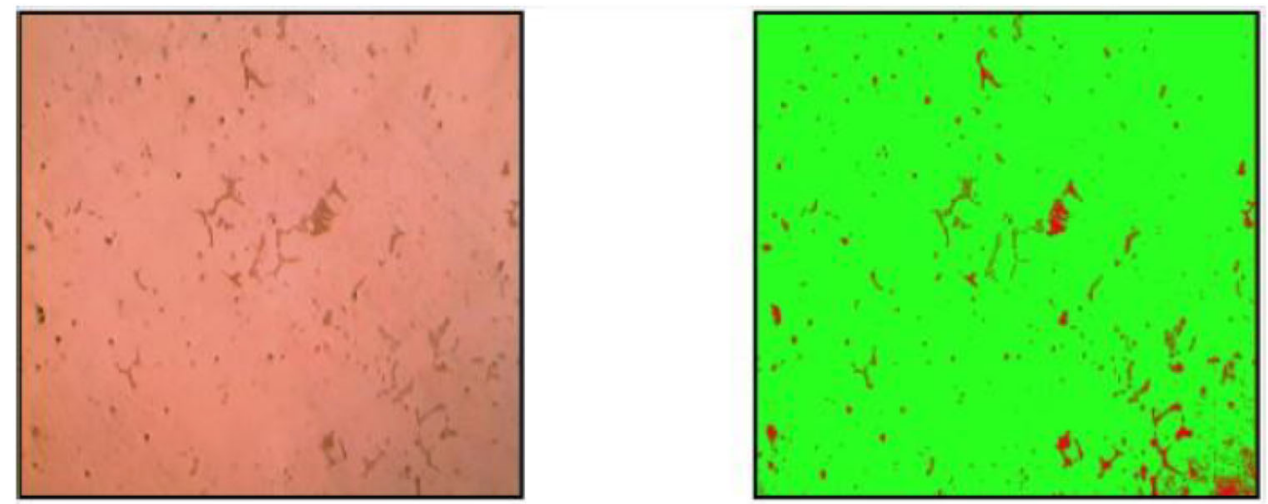

PHASE AND VOLUME ANALYSIS

\begin{tabular}{|l|l|l|l|}
\hline S/No. & NAME & AREA & AREA PER \\
\hline 1 & d-ferrite & 35735.491 Micron Sqr & 3.474 \\
\hline 2 & Austenite & 992835.938 Micron Sqr & 96.526 \\
\hline
\end{tabular}

Fig. 8 Delta ferrite estimation of Steel 4 and 5 according to ORNL diagram

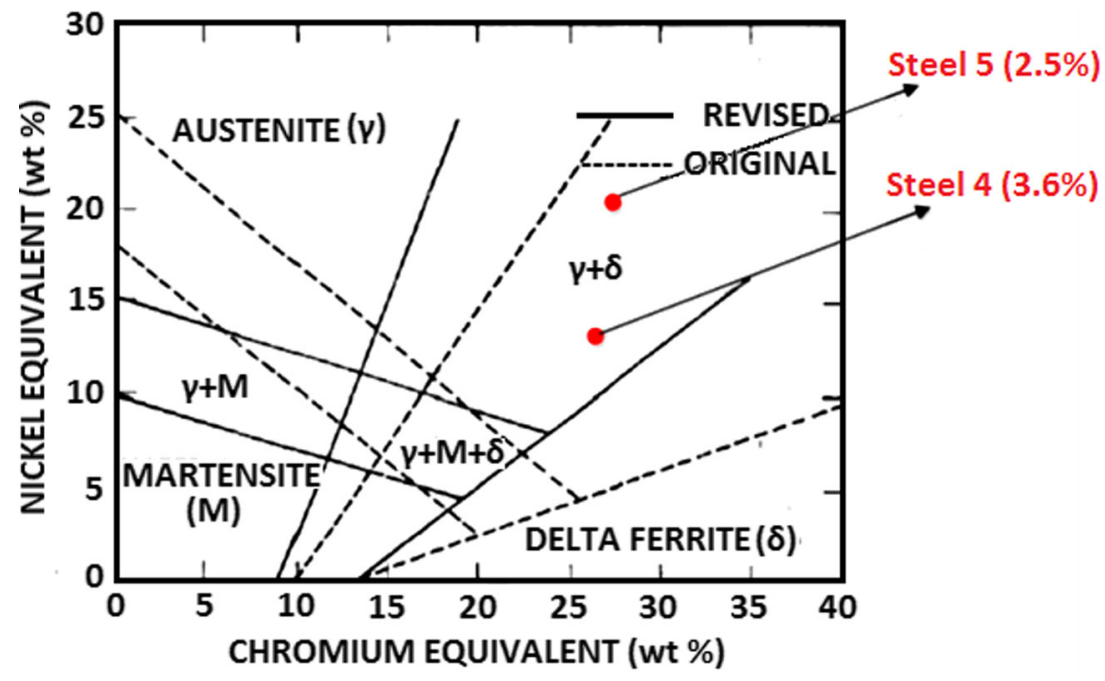


thus the need for comparative data on delta ferrite composition [17, 18].

The delta ferrite content of steel 5 is determined within the range of $1-4 \%$ with both methods confirming the approximations made by the ORNL constitution diagram. Delta ferrite contents of samples 4 and 5 measured by metallographic image analysis and feritscope ${ }^{\circledR}$ methods are similar. Figure 8 represents the estimation of delta ferrite content of steel 4 and steel 5. Based on the estimate, delta ferrite content of the exact composition of sample 5 is about $2.5 \%$, while the value for sample $4(316 \mathrm{~L})$ is about $3.6 \%$. Microstructural transformation associated with delta ferrite content can result in serious setbacks at temperatures above $315{ }^{\circ} \mathrm{C}$. Steels with delta ferrite content involved in high temperature application in the range of 425 to $650{ }^{\circ} \mathrm{C}$ experiences selective carbides precipitate at ferrite sites instead of the austenite phase which eventually results in loss of mechanical properties above $540{ }^{\circ} \mathrm{C}$ due to the formation of sigma or chi $(\chi)$ phases. Above $540{ }^{\circ} \mathrm{C}$, the phases impact on the toughness, corrosion, and creep resistance of the steel.

\section{Mechanical Test Analysis}

Results of the mechanical test (Tables 11, 12, 13, 14, 15) especially the Charpy impact show that the toughness of all the 5 steel samples has been reduced significantly after the galvanized heat treatment which took 21 days at $460{ }^{\circ} \mathrm{C}$. This results in fissures in welded areas such as the flanges and necks of sink rolls, and fracture of their bearings and locking rotation even at relatively low application of stress. This shows that stainless steels with high temperature strength coupled with toughness is the objective of sink roll fabrication. The Charpy impact value of the steels samples reduced significantly. The impact testing results for sample 1 lost $78.5 \%$ of its toughness, while samples $2-5$ lost 28.3 , $29.8,95.3$, and $48 \%$ of their toughness, respectively. In practical application, reduced toughness leads to poor resistance to cracking. The toughness values of sample 2, sample 3, and sample 5 are much lower than samples 1 and 4 (AISI 316L), and thus they are more superior.

The results of the tensile test show that all the steel samples retained their elongation and reduction of area values with the exception of AISI 316L. AISI 316L proves to be brittle behavior due to sensitization as a result of higher delta ferrite content. The results prove that samples 2, 3, and 5 are excellent for application as sink roll material. AISI 316L lost $95 \%$ of its initial impact energy and $82.6 \%$ of its initial reduction of area, while it retained about $50 \%$ of its impact energy and virtually most of its reduction of area values. AISI $316 \mathrm{~L}$ proves to be very brittle after the galvanizing regime. Its tensile strength increased by $28 \%$, yield strength decreased by $37.6 \%$, and elongation decreased by $38.52 \%$ with its toughness value. Visual observation shows that samples 2, 3, and 5 are much better than AISI 316L based on mechanical properties for the galvanizing conditions due to the higher delta ferrite content of AISI 316L and the absence of microalloying elements such as vanadium which is a stabilizing element. Vanadium precipitates with $\mathrm{N}$ and $\mathrm{C}$ before any other element in steel and exhibits fine precipitation. This helps avoid sensitization and increases high temperature and creep strength of the steel samples as a microalloying element [26]. The higher nitrogen content of steel samples 2, 3, and 5 is also responsible for their better mechanical properties. Nitrogen is a strong austenite stabilizer which reduces the delta ferrite content of stainless steels. Its presence within the microstructure increases the strength of steel [27].

Table 11 Mechanical tests results of steel 1

\begin{tabular}{lccccc}
\hline Condition & Tensile strength, MPA & Yield strength, MPA & Elongation, \% & Reduction of area, \% & Impact energy, J \\
\hline Solution annealed & 591 & 164 & 51.8 & 47 & 208 \\
Exposed to $460{ }^{\circ} \mathrm{C}$ & 702 & 182 & 54.8 & 53.5 & 38 \\
Aged at $750{ }^{\circ} \mathrm{C}$ & 524 & 165 & 9.72 & 3.14 & 3 \\
Aged at $750{ }^{\circ} \mathrm{C}$ then exposed to $460{ }^{\circ} \mathrm{C}$ & 529 & 201 & 11.22 & 3.13 \\
\hline
\end{tabular}

Table 12 Mechanical tests results of steel 2

\begin{tabular}{lccccc}
\hline Condition & Tensile strength, MPA & Yield strength, MPA & Elongation, \% & Reduction of area, \% & Impact energy, J \\
\hline Solution annealed & 505 & 141 & 73.58 & 82.7 & 286 \\
Exposed to $460{ }^{\circ} \mathrm{C}$ & 586 & 153 & 65.61 & 70.34 & 205 \\
Aged at $750{ }^{\circ} \mathrm{C}$ & 528 & 179 & 47.5 & 33.11 & 32 \\
Aged at $750{ }^{\circ} \mathrm{C}$ then exposed to $460{ }^{\circ} \mathrm{C}$ & 540 & 152 & 50.84 & 31.76 \\
\hline
\end{tabular}


Table 13 Mechanical tests results of steel 3

\begin{tabular}{|c|c|c|c|c|c|}
\hline Condition & Tensile strength, MPA & Yield strength, MPA & Elongation, \% & Reduction of area, \% & Impact energy, $\mathbf{J}$ \\
\hline Solution annealed & 505 & 141 & 73.58 & 82.7 & 286 \\
\hline Exposed to $460{ }^{\circ} \mathrm{C}$ & 586 & 153 & 65.61 & 70.34 & 205 \\
\hline Aged at $750{ }^{\circ} \mathrm{C}$ & 528 & 179 & 47.5 & 33.11 & 32 \\
\hline Aged at $750{ }^{\circ} \mathrm{C}$ then exposed to $460{ }^{\circ} \mathrm{C}$ & 540 & 152 & 50.84 & 31.76 & 31 \\
\hline
\end{tabular}

Table 14 Mechanical tests results of AISI 316L

\begin{tabular}{lccccc}
\hline Condition & Tensile strength, MPA & Yield strength, MPA & Elongation, \% & Reduction of area, \% & Impact energy, J \\
\hline Solution annealed & 628 & 166 & 43.82 & 75.8 & 71.06 \\
Exposed to $460{ }^{\circ} \mathrm{C}$ & 655 & 177 & 26.94 & 30.91 & 78 \\
Aged at $750{ }^{\circ} \mathrm{C}$ & 535 & 152 & 2.77 & 3.83 & 33.29 \\
Aged at $750{ }^{\circ} \mathrm{C}$ then exposed to $460{ }^{\circ} \mathrm{C}$ & 572 & 174 & 3.83 & 16 \\
\hline
\end{tabular}

Table 15 Mechanical tests results of AISI 316L

\begin{tabular}{lccccc}
\hline Condition & Tensile strength, MPA & Yield strength, MPA & Elongation, \% & Reduction of area, \% & Impact energy, J \\
\hline Solution annealed & 628 & 166 & 43.82 & 75.8 & 150 \\
Exposed to $460{ }^{\circ} \mathrm{C}$ & 655 & 177 & 26.94 & 71.06 & 38 \\
Aged at $750{ }^{\circ} \mathrm{C}$ & 535 & 152 & 2.77 & 30.91 & 11 \\
Aged at $750{ }^{\circ} \mathrm{C}$ then exposed to $460{ }^{\circ} \mathrm{C}$ & 572 & 174 & 3.83 & 33.29 \\
\hline
\end{tabular}

Table 16 Equivalent chromium contents of 5 candidate steels

\begin{tabular}{lc}
\hline Steel no. & Equivalent chromium content \\
\hline 1 & 29.34 \\
2 & 26.03 \\
3 & 24.43 \\
4 (AISI 316L) & 23.42 \\
5 & 25.45 \\
\hline
\end{tabular}

Mechanical test results from the other heat treatment conditions (aging at $750{ }^{\circ} \mathrm{C}$ for $16 \mathrm{~h}$ to combine vanadium with carbon and nitrogen and the two-stage heat treatment consisting of aging at $750{ }^{\circ} \mathrm{C}$ and the other at $460{ }^{\circ} \mathrm{C}$ at $504 \mathrm{~h}$ ) show that the entire steels samples have diminished mechanical properties. Sample 2 shows the best results among the 5 samples; however, its toughness reduced by $89.2 \%$, while AISI 316L had the worst result with its toughness reduced by $99 \%$. The loss in mechanical properties is due to the formation of the sigma phase. Table 16 depicts the equivalent chromium content values of the steel samples.

The ferrite phase in stainless steel transforms to sigma phase at temperatures above $540{ }^{\circ} \mathrm{C}$. Austenite also transform to sigma phase directly. Stainless steel with equivalent chromium content greater than (17-18)\% experience sigma phase formation as shown in Table 14. It is suggested that aging treatment at $750{ }^{\circ} \mathrm{C}$ results in the formation of sigma phase in the steel samples coupled with the loss of initial toughness and ductility [28, 29]. In summary, samples 2 and 5 have the best mechanical properties for application in the fabrication of sink rolls for use in galvanizing baths.

\section{Conclusion}

Sink roll must be capable of passing as much steel strip from galvanizing bath without causing any mark on strip, slippage, locking of line, vibration, or waving. It has to be corrosion resistant in order not to mark the steel strip passing on. Analysis of the corrosion resistance and mechanical properties for the tested steel samples for industrial application as sink rolls gave the following results:

1. AISI $316 \mathrm{~L}$ had the lowest corrosion resistance and mechanical performance among the tested alloy samples due to its higher delta ferrite content which is responsible for sensitization, hence sigma and chi phase precipitation. This causes it to lose its toughness and corrosion resistance.

2. Result from mechanical tests performed at 4 different heat treatment conditions shows that steels 2 and 5 are 
reasonably strong, while steel 1 and AISI 316L were enormously embrittled. Aging treatment at $750{ }^{\circ} \mathrm{C}$ failed to improve mechanical properties of these steels.

3. Corrosion test results show that corrosion rates of the steel samples are indirectly proportional to the immersion time due to the formation of corrosion products over the steel surface which eventually slowed down the corrosion rate. Aging did not affect corrosion rates and mass loss per unit area of the steels except for AISI 316L.

4. The combined assessment of immersion corrosion and mechanical testing results shows that steel 2 and steel 5 were the best 2 steels. Steel 3 has a performance which is closer to steel 2 and 5, while steel 1 and steel 4 (AISI $316 \mathrm{~L}$ ) have weak performance in comparison to other steels.

Acknowledgments The authors acknowledge the Department of Metallurgical and Materials Engineering, Faculty of Engineering, Middle East Technical University, Ankara, Turkey for the provision of facilities for this research.

\section{References}

1. Benefits of galvanizing. http://www.gaa.com.au/index.php?page= 10-benefits-of-galvanizing. Accessed 24 Feb 2016

2. A. Hegyi, M. Pastrav, O. Cazan, Economical advantages of corrosion protection by hot-dip galvanizing of steel structures, in The International Scientific Conference Communication, 3rd edn, Context Interdisciplinary (Targu-Mures, 2014), pp. 251-263.

3. International Lead and Zinc Study Group, World Directory: Continuous galvanizing lines (International Lead and Zinc Study Group, Lisbon, 2010), pp. 9-77

4. M.A. Bright, Dissolution and diffusion characteristics of $316 l$ stainless steel in molten zinc containing variable concentrations of aluminum in Mechanical Engineering (West Virginia University, Morgantown, 2007), pp. 4-36

5. M.S. Brunnock, R.D. Jones, G.A. Jenkins, D.T. Llewellyn, Interactions between liquid zinc and bath hardware materials in continuous galvanizing lines. Ironmak. Steelmak. 23(2), 171-176 (1996)

6. M.S. Brunnock, R.D. Jones, Supermeniscus interactions between molten zinc and bath hardware materials in galvanizing. Ironmak. Steelmak. 24(1), 40-46 (1997)

7. J. Xu, A.B. Mark, X. Liu, Liquid metal corrosion of 3161 stainless steel, 410 stainless steel and 1015 carbon steel in a molten zinc bath. Metall. Mater. Trans. A 38A, 2727-2736 (2007)

8. K. Zhang, N. Tang, E.G. Frank, S. Sexton, Reaction of 316L stainless steel with a galvanizing bath. J. Mater. Sci. 42, 97369745 (2007)

9. X. Liu, E. Barbero, J. Xu, M. Burris, K. Chang, V. Sikka, Liquid metal corrosion of $316 \mathrm{~L}, \mathrm{Fe}_{3} \mathrm{AI}$, and $\mathrm{FeCrSi}$ in molten $\mathrm{Zn}-\mathrm{AI}$ baths. Metall. Mater. Trans. A 36A, 2049-2058 (2005)
10. A.B. Saurabh, S.D. Kshirsagar, Improving the sink roll life in galvalume using material AT101 and the various thermal-spray coating on stainless steel $316 \mathrm{~L}$ roll surface. Int. J. Soft Comp. Eng. 3(1), 282-286 (2013)

11. ASTM, Standard Practice for Preparing, Cleaning, and Evaluating Corrosion Test Specimens, ASTM, G1-03 (ASTM, West Conshohocken, 2003)

12. ASTM, Standard Practice for Laboratory Immersion Corrosion Testing of Metals, ASTM G31-72 (ASTM, West Conshohocken, 2004)

13. European Committee for Standardization, Metallic MaterialsTensile Testing, Part 1: Method of Test at Ambient Temperature, EN (European Committee for Standardization, Brussels, 2001), p. 10002-1

14. European Committee for Standardization, Metallic materialsCharpy pendulum impact test in Part 1: Test Method, EN ISO 148-1 (European Committee for Standardization, Brussels, 2009)

15. G.W. Dallin, Hot-dip coated sheet products, Metallic Coated Products and Specifications (International Zinc Association, Durham, 2011)

16. G.W. Dallin, Continuous hot-dip galvanizing versus general (batch) galvanizing, Coating Processes and Surface Treatments (International Zinc Association, Durham, 2011)

17. J.C. Tverberg, The role of alloying elements on the fabricability of austenitic stainless steel, 2003

18. M. Prager, Cast High Alloy Metallurgy, Steel Casting Metallurgy (Steel Founders' Society of America, Crystal Lake, 1984), pp. 221-245

19. C.E. Bates, L.T. Tillery, Atlas of Cast Corrosion-Resistance Alloy Microstructures (Steel Founders' Society of America, Crystal Lake, 1985)

20. G.W. Dallin, The role of aluminum in continuous hot-dip galvanizing, Coating Processes and Surface Treatments (International Zinc Association, Durham, 2011)

21. G.W. Dallin, Zinc bath management on continuous hot-dip galvanizing lines, Coating Processes and Surface Treatments (International Zinc Association, Durham, 2011)

22. G.W. Dallin, Galvanneal-differences from galvanize, Metallic Coated Products and Specifications (International Zinc Association, Durham, 2011)

23. A.R. Marder, The metallurgy of zinc-coated steel. Prog. Mater. Sci. 45(3), 229-232 (2000)

24. J.R. Davis, ASM Specialty Handbook, Stainless Steels (ASM International, Materials Park, 1994), pp. 3-66

25. R.L. Klueh and P.J. Maziasz, Reduced activation austenitic stainless steels: The Fe-Mn-Cr-C system. http://www.osti.gov/ bridge/servlets/purl/7170951-M3Blhg/7170951.pdf. Accessed 02 Feb 2016

26. J.R. Davis, ASM International Handbook Committee, Metals Handbook, 2nd edn. (ASM International, Materials Park, 2008)

27. G. Harris, N. Setargew, D. Willis, Hot dip Coating Apparatus, United States, 2006

28. V.G. Gavriljuk, H. Berns, High Nitrogen Steels: Structure, Properties, Manufacture and Applications (Springer, Berlin, 1999), p. 378

29. A. Courtesy, Cast Stainless Steels, ASM Handbook, vol. 1 (ASM International, Materials Park, 2005) 